\title{
Education \& Innovation: a Path to Sustainable Development
}

\author{
Adalzira Regina de Andrade Silva \\ SENAC-SP \\ E-mail: adalzira@sp.senac.br \\ Andyara de Santis Outeiro \\ GEPI, Educational Program, PUC-SP \\ E-mail: andy.santis@uol.com.br \\ Ivani Catarina Arantes Fazenda \\ GEPI, Educational Program, PUC-SP \\ E-mail: jfazenda@uol.com.br
}

\begin{abstract}
This article aims at reflecting upon the innovation and the role of education in the broadening of human consciousness through the perspective of sustainable development of society. It points out some principles that drive the collaborative innovation and the role of technology and connectivity in this process. We emphasize the contributions of interdisciplinary education and the responsibility of the educations as an agent in the society transformation process towards humanization.
\end{abstract}

Keywords: Innovation; Education; Interdisciplinarity; Sustainable development.

\section{Introduction}

We are living a moment in mankind history in which the breakdown of natural resources live together with the waste and inefficiency of these resources usage. The unbridled consume results in the excess of garbage and toxic residues that pollute the atmosphere. The soil and the water, hunger and scarcity live together with health problems related to obesity. The continuous global richness is not enough to reduce the distance between rich and poor people. The global corporative cultures make an effort to homogenize historical and cultural differences among nations. Contrasts and contradictions translated into complex challenges to the governments, companies and civil society. In this context, the demand for innovation is patent and urgent.

According to Houaiss", innovation means "action or effect of innovating" - that may be defined as "to become new; renew, restore" and "introducing the new; do something as it had never been done before". Man is, in essence, an innovative being, since he recognizes himself as Homo sapiens ..., from the well succeeded combination of its telencephalon developed with its opposite thumb. Being so, it is supposed that it was not exactly the ability of innovation, of doing things as it had never been done before that puts us in the situation we have been living now. 
We believe, it is necessary to analyze how much we culturally win or lose with the great actual change that the "soft" technologies have provided $u^{2}$. These technologies have been uprising and deal with techniques of informational nature that have followed us in the hominization process - as the invention of writing, for example, in which the historian André Leroi-Gourhan described as the hominization process: "Man, when he stands up for locomotion, he liberates his arms, members for transportation functions till then. His hand can now develop the capacity of grabbing things, and then man becomes Homo Faber. When he gets his hands to grab things, the mouth, which had previously this function, looses it. Mouth can now speak... ..."(SERRES, 2001, p.15) ${ }^{3}$

The last centuries have been characterized by an extensive variety of innovations, mostly technological, generally conceived to attend the expectations of the economical growth of hegemonic groups dominant in society. The mechanization of the productive processes reduced expenses, generated unemployment, increased mass production of itemspreviously unknown and now considered essential to human existence. The increasing of technology at work appeared as a promise for more life quality to the people as work could be done more quickly, with time left for other activities. What happened was the increase of the demand for quickness generating an overload of work that became the main human activity, invading the other spaces and occupying most of people's free time due to the connectivity provided by the internet and mobile technologies.

We understand that simply including technology does not become the processes more innovative. Being so, we propose to widen up our view to "Technology in education" - that embraces informatics but it is not restricted to it. It also includes uses of other communication medias as television, videos, radios and also cinema. We understand technology as being the result of a fusion between science and technique. The concept of educational technology may be announced as a set of procedures (techniques) that can "facilitate" the teaching-learning processes through the use of means (instrumental, symbolic or organizational ones) and their consequent cultural transformations.

The use of educational technology is not recent. The education, organized since the beginning, uses different educational technologies according to each time in History. The chalk and blackboard technologies, for example, are used until nowadays by most of the schools. Also, the textbook technology still persists in the times of information and knowledge. In the 50 's and 60's the educational technology was seen as synonym of didactic resources. From the 60 's on, the development of mass media communication began to revolutionize the world in all segments - mostly in education.

As time passed, the technology became more complex and the use of rules demands a more accurate cognitive control. The problem is how to make the most of these resources in order to broaden the human's minds horizons towards the search for solutions for the challenges of our times. In fact, one of the greatest challenges of the contemporary world consists of finding ways for the technology and education, as well as for the actual electronic medias, to walk together searching for the necessary innovations to the new world in transition in which we live in - with new educational sites, new ways of connecting ideas, new ways to rescue and fortify more humanized relationships. This transition requires us to find an equilibrium betwe- 
en production and consume - where the discovery of this magic formula urges. We should mention Bergman saying that we are living a consuming era and entering the protectional and environmental era.

So, we ask: how are these new soft technologies favoring the hominization process, integrating individual accesses to the collective memory, providing conditions to explore and discover other spaces and possibilities of creative realizations? Considering that culture does not have boundaries ant it is permeable $e^{4}$, the "true" culture is not in danger as we live a considerable transformation of the cognitive subject, of the objective science and of the collective culture - such a movement that is even more explored by the innovative Technologies and potential social networks. "In fact, these communication means are considered universal and can connect us immediately with any spot on Earth, the way we use them is surprisingly local1"! (SERRES, 2001, p.17) ${ }^{5}$

From the global to the local; from the individual to the totality, we can notice that even more it is necessary an interdisciplinary negotiation focused on the BEING - which helps in this process of finding the conducting wire between the evolution and innovation andthe Technologies turned to an education that humanizes, so that, each person can, humbly, find his/her own creative freedom inside the spaces provided for the collective access.

Thus, when we consider innovation as a necessary act for humanity in order to face the actual challenges, it is important to distinguish the type of innovation we wish. It is not a question of simply innovating or only innovating in any direction.

Our demand is for innovations that serve the collective wellness, that "attend the human necessities of today without risking the capacity of the new generations to satisfy their own needs" ${ }^{\prime \prime}$. Innovations that can integrate the actual challenges of society in search for a development that is, at the same time, economically possible; environmentally correct;socially fair and culturally inclusive. Innovations towards a sustainable development of the society.

Any innovation that priorizes any of the above dimensions in detriment to the others is not desirable. It is not enough to innovate for the economical growth without considering the social, environmental and cultural impacts. This has been the inclination of the innovations until today - that is what brought us here. Also, innovating only in order to look for an environmental equilibrium, without the economical feasibility, social justice and cultural inclusion would be unbearable.

Innovation in this context, could demand an extreme break which would impose a radical analysis of the consumerist life style that is deep-rooted in a considerable part of our society, preventing the excluded historically peoples of the capitalist system from using the immediate consume "benefits". Innovations turned only to social justice without considering the other impacts may be also dangerous. We may point at the plannedeconomy and totalitarian systems that in order to favor the social wellness also limit the citizens freedom or even worry about preserving the natural resources.

The challenge to innovate towards a sustainable development will depend on the political, economical, social, technological and cultural efforts. Among them, we emphasize education as one of the main components necessary to promote the broadening of the human consciousness in this direction, as GUEVARRA (1998) points out:"Innovation merges from ideas connected in net by one society committed to the citizenship exercise and to a conscious 
citizen. A citizen worried with his/her problems and aware of attitudes and motivations in the search for solutions that provide equilibrium of the relations between man and environment, so that future generations won't be victims of the devastating actions conducted by man, which already compromised our future." (GUEVARA et al, 1998) ${ }^{7}$

\section{The Necessary Education}

In the 21st century, the education will be based on four main basis ${ }^{8}$ : learning how to learn; learning how to do; learning how to live along with; learning how to be. The educational institutions will have to change their route, searching for alternatives and methods that promote, not only technical knowledge but also that join themselves in order to promote the individual plenitude, awakening abilities of an ethical, human and political relationship - that composes the essence of citizenship and that are the basis of any developmental action desirable for the whole life, i.e., which inserts into a permanent educational perspective.

The biggest challenge faced by humanity is not restricted to academic environment with scientists and politicians that rein sovereignty in order to decide the destiny of society. It has become even clearer that the construction for a more sustainable society is on the hands of each citizen starting from his own choices and actions which will influence and provoke changes "inside the system".

The "system" is our organizations, cities and communities. They got sick throughout the last centuries as they promoted innovations that prioritize the economical growth in detriment to the social, environmental and cultural dimensions. There is no more space for wasting, losses, environmental destruction or social inequality. We urgently need the capacity of looking at the possibilities in a different way and of conceiving them through a new perspective: the sustainability perspective.

When we talk about educating for sustainability we talk about educating for integration, for the non-fragmentation of the thought. In order for an individual integrate social AND economical AND environmental AND cultural aspects at the same time in his daily decisions, it is very important that he develops an interdisciplinary and systemic view which comprehends: a dynamism among many elements of the system; the forces that rule this interaction; the circular movement among causes and consequences; the mental systems and the invisible systemic structures that shape the visible events.

We need a new educational pathways able to construct the basis for the individual, since his childhood, so that he becomes able to develop thinking abilities in terms of connections, relations, context, interactions among the elements as a whole; to see things in terms of network and communities. A innovation that allows him to see "processes" in any phenomenon, changes (real or potential), growth and development; to recognize that our perceptions are conditioned by our methods and questionings ${ }^{9}$.

We need to create new spaces for dialogues that allow this change and that awaken on people the sensibility and generosity necessary to take care of our world. 


\section{The Contribution of Interdisciplinarity}

The interdisciplinarity theory borrows the metaphor of the sight in order to explain the comprehension about the different lenses through which we represent the world and that guide our actions (FAZENDA, 2002).

When we long for an educational model that contemplates the different dimensions of reality in order to promote more comprehensive innovations towards the sustainable development, we are considering a model that comprises the necessity to establish partnerships among many sectors of society as well as among the different actors of the educative process and among different subjects in order to favor a collective construction. We point out another contribution of the interdisciplinarity that teaches us the following: "For a better comprehension of reality, the change must be focused on partnership, because we don't live alone, we need the other's vision, because the other understands, analyzes, lives and observes from a different angle, amplifying our own vision". (ARNT in FAZENDA, 2002, p. 74) ${ }^{10}$

With the fragmentation of knowledge we live in what we can call the crisis of science. This crisis has been proclaimed by many people in different school lines in different countries. It is mentioned the crisis of theory, models, paradigms and what we have to do is: "It's necessary to study the problematic and the origin of all uncertainties to conceive an education able to face them. Everything seems to prove us that the exercise of interdisciplinarity would make it easier to face the knowledge and science crisis. Although, it's necessary to understand the dynamic lived by this crisis and to perceive the importance and the dilemmas to be overcome in a project that contemplates it.".(FAZENDA, 2001, p.14)

Nevertheless it is important to highlight that the fragmentation movement may unleash the immediacy in the answers and result in an action of "joining disciplines" and the interdisciplinarity that we are discussing here points to a bigger necessity to think of complexity and not simply in the creation of one or more other disciplines (SOUZA, 2010).

Overcoming the barriers among the disciplines through a dialogical process and partnership, would be possible to construct a more comprehensive knowledge that could amplify the sight in order to face challenges. According to Fazenda (2011, p.89), "the passage from knowledge to action, because of its own complexity, involves a series of social and natural phenomena that will demand an interdependence of disciplines as well as the appearance of new ones".

\footnotetext{
"Many attempts to find an unquestionable methodology for interdisciplinarity were conducted by researchers, however what they have discovered was just misunderstanding due to limitations such as the impossibility of an unifying language of sciences and in consequence, limitations to create a comparative methodology in human sciences. Nevertheless, from the assumption that an interdisciplinary methodology requires its own method, Fazenda believes that the interdisciplar discourse is the most natural method for the role of interdisciplinarity. Such a method merges from the involvement of complexity and the participation on questioning, researching and inquiring." (FAZENDA, 1994, p. 68).
}

Thus, the necessary education to promote innovations towards the sustainable development can clearly benefit itself from interdisciplinarity.

We believe that in the interdisciplinarity we can find more questions that may help to answer many existing questions about how to solve the equation education and innovation. In the same direction, Smirnov says that interdisciplinary tends to convert itself in one of the most important theoretical data that allows to explain the relationship between development and social progress. (FAZENDA, 1994, P.28). 
WITH his interdisciplinary background, Steven Johnson (2010) analyses the principles that defined the technological and scientific innovations throughout the last centuries and that may have favored the exercise of creative human freedom and search for the roots of innovation along the history of science as well as of more contemporaneous examples of innovations either in the academic field or business. The result is a new perspective of innovation that would be provided by an environment where the ideas could have the chance to connect among themselves and collaborate in open networks. "When somebody observes innovation in nature and culture, environments that construct walls around good ideas tend to be less innovative in long term than more open ones. Good ideas don't want to be free. They want to connect, merge, recombine; they want to complement to each other at the same time they compete among themselves". Positively with SENGE (2009): "Competition and collaboration are not excludent actions like "or-or"; in effect, the term to compete comes from Latin competere, which means "fight together". This basic information exchanged among competitors provide everybody with the knowledge of the situation of common resources that offer the essential conditions for a healthy competition." (SENGE, 2009, p. 170)12

To Johnson, good ideas are not solitaire innovations of the human mind, but a mixture of other ideas, insights and tips that join themselves in a more productive and intellectual environment. "A solitaire genius is rare in the History of innovations".

Thus, technology and connectivity may act favoring innovation, constructing bridges and reducing distances between the solitaire minds, having clearer purposes of constructing innovative solutions for the challenges of society.

In this context, the interdisciplinary negotiation with the engagement of students, teachers and scientific community, encouraged by the directors of schools and other educative spaces can contribute to accelerate this process and promote integrative actions that lead us to a collective learning with new innovative technologies that favor the dialogue among the social relationships.

GUEVARA $(1998,2011)$ leads us to reflect with MORIN $(2000)$ about the role of education and the educator to answer these challenges: "What we defend is that to educate means to conduct and organize the thought (Morin, 2000), to help in the development of logic models for the comprehension of the world which foster the development and the expression of positive thoughts, of self respect and also respect for the others, the development of solidarity, of love for nature and even the fight spirit (Morin, 2002). Education for a sustainable development, in a general consensus among modern educators, should not only instruct, but develop the critical capacity, the spirit of initiative and the sense of responsibility of the educator in the world we live in. In this context, the educator's mission is to consider the resources for constructing bridges between the problems of society and the landscape of richness generation, showing that the sustainability of the planet is in our hands."." (GUEVARA, p. 27, 2011)

"Finally, the practice of an education for sustainability might be the connection between the limitations of the appropriate and the excessive use of environment resources. Clearly, only the education is not enough to change the course of the planet, it certainly is a necessary condition for that."(GUEVARA, p. 29, 2011) ${ }^{14}$

RISUS, São Paulo, vol. 3, n. 2, p. 11 - 18, 2012 


\section{Conclusions}

Innovating is part of the human nature. We are learning beings, unconformed, inquisitive - what moves us to a state of constant transformation. Every day we invent and reinvent the world around us - what Paracelsus had already described as "learning is our own lives - from youth to old age. In fact, almost until death. Nobody spends ten hours without learning anything".

The state of disequilibrium that we generate with so many innovations invites us now to recreate our existence in this planet in a more harmonic and sustainable way. We have the responsibility of innovating towards a development that guarantees our survival and also that attends the needs of the next generations.

In order to face the collective and complex challenges, the most well succeeded innovations will result from the collaboration, connection of ideas and convergence of purposes. So, the education assumes the fundamental role of awakening the human mind towards this direction since it can contribute to overcome the barriers of thought and disciplines, starting from an interdisciplinary negotiation focused on the BEING, which helps in this process of finding a conducting wire between the evolution and innovation of technologies turned to a humanized education.

\section{Notes}

${ }^{1}$ Houaiss, important Portugueselanguagedictionaire.

${ }^{2}$ Michel Serres, in MARGEM, Dossie: War and Peace - Communication against culture - Between Disnayland and the Ayatollahs - Michel Serres is a philosopher, member of the French Academy, author of Hominescences (Paris, Le Pommier, 2001) and Retour au contrat naturel (Paris, Bibliothèque National de France, 2000), among others.

${ }^{3}$ Our translation.

${ }^{4}$ Porous Culture, Concept of Serres. Global examples of this porosity mentioned by the philosopher: Molière Inspired by the Italians or Corneille by the Spanish.

${ }^{5}$ Our translation.

${ }^{6}$ Worldwide Commission on Environment and Development.Our Common Future. Rio de Janeiro: Ed. FGV, 1988.

7 Our translation.

${ }^{8}$ According to Jacques Delors's report, "Education - a treasure to be discovered" (UNESCO, 1996).

${ }^{9}$ Andrade, Aurélio ... [et al] - Systemic Thought: Field Note: The callenge of sustainable change on organizations and society. Porto Alegre - Bookman, 2006.

${ }^{10}$ Our translation.

${ }^{11}$ Our tranlation.

${ }^{12}$ Our translation.

${ }^{13}$ Our translation.

${ }^{14}$ Our translation. 


\section{References}

[1] Almeida Fernando José. Educação e Informática - Os computadores na escola. Editora Cortez, 2005 (In Portuguese)

[2] Andrade Aurélio... [et al] - Pensamento Sistêmico: Caderno de Campo: o desafio da mudança sustentada nas organizações e na sociedade. Editora Bookman. Porto Alegre, 2006 (In Portuguese)

[3] Arnt Rosamaria de M. in Fazenda Ivani C.A (org.). Dicionário em construção: Interdisciplinaridade. 3. Editora Cortez. São Paulo, 2002 (In Portuguese)

[4] Bauman Zygmunt. Modernidade Líquida. Editora Zahar. Rio de Janeiro, 2001 (In Portuguese)

[5] Fazenda Ivani C. Arantes. Interdisciplinaridade: História, Teoria e Pesquisa. Editora Papirus, 1994 (In Portuguese)

[6] Fazenda Ivani C.A. Integração e Interdisciplinaridade no Ensino Brasileiro. Efetividade ou Ideologia. 6. Edições Loyola. São Paulo, 2011 (In Portuguese)

[7] Guevara A.J. de H; DIB, V. C. Educação para a Era da sustentabilidad. Editora Saint Paul. São Paulo, 2011 (In Portuguese)

[8] Reis J. B. A.O conceito de tecnologia e tecnologia educacional para alunos do ensino médio e superior. Disponível em: http://alb.com.br/arquivo-morto/edicoes_anteriores/anais17/txtcompletos/sem16/COLE_932.pdf > Acesso em 22/09/2011 (In Portuguese)

[9] Senge Peter M. (et al). A revolução decisiva: como indivíduo e organizações trabalham em parceria para criar um mundo sustentável. Editora Elsevier. Rio de Janeiro, 2009 (In Portuguese)

[10] Serres M. A comunicação contra a cultura. Entre a Disneylândia e os aiatolás. Editora Margem, N. 14. São Paulo, 2001 (In Portuguese)

[11] Souza F.C. Do mito de Quíron à construção da metáfora da cura na escola. Tese de Doutorado. Pontifícia Universidade Católica de São Paulo. São Paulo, 2009 (In Portuguese)

[12] Steven Johnson. Where Good Ideas Come from. Ed. Penguim. USA, 2010

[13] WCED - Comissão Mundial sobre Meio Ambiente e Desenvolvimento. Nosso Futuro Comum. Editora da FGV. Rio de Janeiro, 1988 (In Portuguese)

[14] Senac Proposta Pedagógica. Disponível em: http://www.sp.senac.br/pdf/29550.pdf. > Acesso em 25/09/2011 (In Portuguese) 